DOI https://doi.org/10.36059/978-966-397-207-7/143-161

\title{
INTEGRATIVE DOCTRINE OF LEGAL ASSISTANCE AND PROTECTION IN THE CRIMINAL PROCESS OF UKRAINE
}

\section{Tertyshnik V. M.}

\section{INTRODUCTION}

Ukraine tries to implement a multifaceted and noble idea of the rule of law in public relations, an important component of which is to ensure the rule of law in the field of justice. Judicial and legal reform in Ukraine has made some steps in this direction, but it has not ensured the formation of a holistic doctrine of legal aid and protection.

The norm «Exclusively a lawyer shall defend against criminal charges» (article 131-2) is fixed in the Constitution of Ukraine by the newly elected Parliament of Ukraine, under the slogans of abolishing the monopoly of lawyers to perform the functions of protection and legal assistance in 2019. On the one hand, the «advocate's monopoly» in criminal proceedings leaves unchanged and, on the other hand, the concept of «prosecution» in the law is insufficiently legally certain, because in the pre-trial stages of criminal proceedings against persons who are held to responsible, the act of notification of suspicion is done. So the question about subjects of protection from the ongoing public act of suspicious.

The doctrine of legal aid is a holistic and harmonious system of principles, beliefs, perceptions, ideas, concepts and model rules concerning the formation of the legal Institute and operationalize effective legal assistance to persons entering in any relationship. It is based on intellectual, spiritual, cultural and scientific development of society, state, morality, and the political and ethical culture of a holistic and harmonious system of principles, beliefs, perceptions. It is a system of knowledge, which is the core theoretical and conceptual framework of law-making, law enforcement and the right of interpretation activities, which is aimed at ensuring rule of law in the state. 
Legal assistance is activity of lawyers, which is focused on the rule of law in the state and ensuring the protection of individual human rights, implemented in the form of application of the Institute of protection and other types of legal assistance, the contents of which are: implementation of legal advice and clarification; assistance in preparing and submitting applications, petitions, complaints and other legal documents; initiation and participation in the proceedings and a proper record of their progress and results; assist in the evaluation of supplies, reliability and the admissibility of evidence, the analysis of the legality of legal decisions, taking measures to restore violated rights, compensation for damage caused by the offense.

Separate forms of legal assistance are: a) legal advice, which are held by lawyers and representatives of public human rights organizations and other experts in the field of law; b) representation of the victim (article 58 of the Code of criminal procedure of Ukraine) civil plaintiff, civil defendant; a third party (article 63 of the Code of criminal procedure of Ukraine), and the representation of persons, property of whom can be arrested (article 64-2 of the Code of criminal procedure of Ukraine); C) legal assistance to a witness (article 66 of the Code of criminal procedure of Ukraine); d) protection of a suspect, accused, defendant, convicted and acquitted, a person of whom compulsory medical or educational measures are envisaged and person who can be sent in extradition to a foreign state and a person of whom the Institute of rehabilitation in criminal proceedings is applied.

Forms and methods of legal assistance are not exhaustive and they are formed and developed, they need a clearer legal certainty.

Taking into account the trends of educational reform, multi-level education system and the formation of master's programs today it is advisable to provide a separate discipline «Legal assistance and protection» in the curricula for masters, the content of which would include both legal and organizational, forensic and psychological aspects of providing professional legal assistance and protection. Accordingly, the components of this discipline can be «legal assistance and protection in criminal proceedings"), as the most complex and multifaceted special part of this discipline. It will be right if the scientific specialty $« 12.00 .09$ - criminal procedure and 
criminalistics; forensic examination; operational-search activity» is supplemented with the important direction «legal assistance and protection in criminal proceedings»».

To improve the mechanisms of legal aid and protection, in our opinion, it is necessary to systematize and codify the existing constitutional norms, international legal acts, legislative norms and legal positions and case-law of the European court of human rights, to develop and adopt a separate code - «Code of legal aid and protection».

Protection in criminal proceedings is a kind of legal aid and acts as a legal form of opposition to the prosecution and is carried out by a participant in the criminal process, which is called the defender.

The function of the protection is legal professional activity of specifically authorized to execute it by independent subject of the criminal process - the defender. It is aimed to ensuring the rule of law in criminal proceedings, protection of rights and legitimate interests of the person, who can be brought to criminal liability, denial of suspicion and accusation, the establishment of innocence of a person or the circumstances mitigating her responsibility, rehabilitation of illegally convicted person.

Usually, the exercise of protection in criminal proceedings is often considered in the context of the activities of a lawyer. But the lawyer's activity and the activity of the defender are not identical.

In the modern criminal process, a lawyer, as a representative of a human rights institution, which should do the function of legal assistance, can take part in criminal proceedings in three different statuses: 1) as a defender of a suspect, accused, convicted, acquitted, a person of whom compulsory medical or educational measures are envisaged and person who can be sent in extradition to a foreign state (article 45 Code of the criminal procedure of Ukraine), a person against whom the Institute of rehabilitation is applied in criminal proceedings; 2) as a representative of the victim (article 58 of the Code of criminal procedure of Ukraine) civil plaintiff, civil defendant; a third party (article 63 of the Code of criminal procedure of Ukraine), and as a the representation of persons, property of whom can be arrested (article 64-2 of the Code of criminal procedure of Ukraine); 3) as a legal assistant (consultant) of witness (article 66 of 
Code of criminal procedure of Ukraine) -legal assistance or in other words legal legal counsel.

None of the outlined competencies in Criminal procedure law has received a proper systemic legal definition yet. The law has not adequately regulated both the legal aid function as a whole and the protection function, which creates many problems in ensuring proper justice.

Insufficient clear regulation of the function of protection, means and forms of legal assistance is aggravated with existing legal fictions, lack of legal norms, insufficient logic and terminological shortcomings of the law, they reduce the effectiveness of all criminal legal activities.

It is logical in the Code of criminal procedure of Ukraine to abandon the logic of the concept according to which «the defender uses the rights of the person who is protected by him», and the representative with «rights of the person who is represented by him». This concept has not found continue to provide legal assistance to the witness, the person who came to confession and other participants in the process. Accordingly, there is a need for analogous status of the defender or representative to clearly determine the procedural status of a specialist who will provide legal assistance to other participants in the process, and moreover, in the Code of criminal procedure of Ukraine in certain norms systematically and separately to form the rights in accordance with the «defender», «representative», «legal assistance»».

Article 131-2 of the Constitution of Ukraine with the following content became a novelty of law: «advocacy operates for rendering professional legal assistance in Ukraine. The independence of the advocacy is guaranteed. The principles of the organization and activity of the advocacy and the implementation of advocacy in Ukraine are determined with the law. Only a lawyer shall defend against criminal charges»».

These provisions create a certain competition of legal norms of national legislation and international legal acts, they are internally contradictory and controversial. First, the requirement of Art. 131-2 of the Constitution of Ukraine that «only a lawyer shall defend against criminal charges» does not mean the establishment of a monopoly of lawyers to perform the function of protection in criminal 
proceeding. So according to part 2 of article 42 of the Code of criminal procedure of Ukraine the guilty person is a person, the indictment about him is carried out to the court, according to the article 291 of Code of criminal procedure of Ukraine. Under the current Code of criminal procedure of Ukraine, protection from the act of suspicion is carried out at the pre-trial investigation, and protection from prosecution is possible only in the judicial stage of the process. Consequently, the provisions of the constitutional regulations that «exclusively a lawyer shall defend against criminal charges» do not exclude the protection of a suspect (a person, who has not accused yet) by another lawyer who is not an advocate. Secondly, this novella does not meet the requirements of art. 22 of the Constitution of Ukraine, concerning inadmissibility of restriction of the existing rights and freedoms at adoption of new laws, and also it contradicts the decision of the Constitutional Court of Ukraine ${ }^{1}$, the basic international legal acts ${ }^{2}$ and case practice of ECHR ${ }^{3}$.

The Constitutional Court of Ukraine in its decision on the 30-th of September, 2009 in the case of the constitutional appeal of the citizen Golovan Igor Vladimirovich concerning the official interpretation of the provisions of article 59 of the Constitution of Ukraine (the case of the right to legal aid), determined: 1 . The provision of the first part of article 59 of the Constitution of Ukraine «everyone has the right to legal assistance» should be understood as a state-guaranteed opportunity for any person, regardless of the nature of his legal relations with state bodies, local governments, associations of citizens, legal entities and individuals to freely, without undue

1 Рішення Конституційного суду України у справі за конституційним зверненням громадянина Голованя Ігоря Володимировича щодо офіційного тлумачення положень статті 59 Конституції України (справа про правову допомогу) від 30 вересня 2009 року № 23-рп/2009. URL: http://zakon2.rada.gov.ua/laws/show/v023p710-09/conv

2 Принципи i керівні положення Організації Об'єднаних Націй, що стосуються доступу до юридичної допомоги в системі кримінального правосуддя, Резолюція Економічного та Соціальної Ради ООН 2012/15 від 26 липня 2012 р.) URL: http://search.ligazakon.ua/1_doc2.nsf/link1/MU13168.html

${ }^{3}$ Рішення Європейського Суду 3 прав людини від 24 листопада 2011 року «Загородній проти України», у рішенні (Заява № 27004/06) // Офіційний вісник України» від 18 травня 2012 року № 35. 
restrictions to receive assistance on legal issues in the scope and forms as he requires; 2 . A person during interrogation as a witness in the bodies of inquiry, pre-trial investigation or giving explanations in legal relations with these and other state bodies has the right to legal (juridical) assistance from a person elected at his own request in the status of an advocate, this situation does not exclude the possibility of obtaining such assistance from another person, if the laws of Ukraine don't have restrictions.

The European court of human rights in the case «Zagorodny V. against Ukraine» clearly defined its position. In its decision of the 24-th of November 2011, the European court of human rights found a violation of paragraphs 1 and subparagraph «C» paragraph 3 of article 6 of the Convention, because the applicant's right to free choice of counsel was limited, and the state created a situation incompatible with the principle of legal certainty, which is one of the basic aspects of the rule of law.

The new international legal source of law, such as the «United Nations Principles and guidelines on access to legal assistance in the criminal justice system» (UN Economic and Social Council Resolution 2012/15 of 26 July 2012), should also be guided by the conceptually appropriate provisions for democratic societies in addressing the problem of the range of persons who can serve as a defender in criminal proceedings. Let us take attention, in particular, to its main concepts and provisions aimed at expanding access to legal assistance in criminal justice systems: «the person providing legal assistance is called a» legal counsel», that is, a legal adviser; «States use various forms of legal assistance, it can be public defenders, private lawyers, lawyers by agreement, paralegals and others»; " without prejudice to the rights of the accused, legal assistance should be provided to victims and witnesses at all stages of criminal justice»; «States should recognize and encourage the contribution of the Bar Association, universities, civil society and other groups and institutions in the provision of legal aid»; in order to facilitate the functioning of the national legal aid system, if it is necessary, States should, take measures to:.. «to enable paralegals to provide the forms of legal assistance permitted by domestic law or practice to arrested, detained, suspected or accused persons of a 
criminal offence, in particular in police stations or other places of detention.»..» ${ }^{4}$.

First of all, in the Code of criminal procedure some gaps should be removed on the definition of the status (including the right to protection) about following persons: a) persons appearing to confess; b) persons, who actually became under investigation because of registered statement about the crime, but he is not detained and has not reported about suspicion yet (has not received the status of a suspect); C) persons who have committed socially dangerous acts, but have not reached the age of criminal responsibility; g) persons who have committed socially dangerous acts in condition of insanity and in respect of which the investigation is being carried out.

In this aspect, the criminal procedure legislation of Germany was explored. In the Code of criminal procedure of Germany four concepts are applied respectively to stages of process: «verdachtider» - the person concerning whom there are bases for suspicion him in commission of crime; «berschuldigter» - the person concerning whom criminal procedural production is carried out;» angeschuldigter «-the person concerning whom the charge is brought; » angeklagter» - the defendant.

We propose to establish a single status - «under investigation»in respect of all named persons who become parties to criminal legal relations. In the Ukrainian language synonyms of the word «suspicion» are the words «assumption» and «doubt». The «doubtful» participant in the process is the bitter reality of the present. The use of the term «under investigation» would be more correct. It indicates the actual position of the person, and not a subjective view of the situation on the part of the investigator. In addition, it is stylistically neutral and from the whole synonymous series has minimal expression, carries less emotional coloring. It is characteristic that in relation to the stage of the trial, the legislator has long used the term «defendant».

4 Принципи і керівні положення Організації Об’єднаних Націй, що стосуються доступу до юридичної допомоги в системі кримінального правосуддя, Резолюція Економічного та Соціальної Ради ООН 2012/15 від 26 липня 2012 р.) URL: http://search.ligazakon.ua/1_doc2.nsf/link1/MU13168.html 
The use of the term «suspect» should be abandoned, because it has more elements of subjectivity and is not associated with the actual state of the person. And this condition of the specified persons is a condition which is covered by the universal concept- «the person under investigation»».

It is necessary, fulfilling the requirements of part 2 of article 5 of the European Convention for the protection of human rights and fundamental freedoms, to restore the concept of a preliminary investigation - « the accused". It defines: «Everyone who is arrested must be immediately informed in a language understandable to him the reasons for his arrest and any charge brought against him».

Therefore, at the pre-trial investigation in respect of persons against whom the proceedings are carried out, two possible statuses must be legally defined - the defendant and the accused, accordingly in court the accused becomes the defendant.

Therefore, in our opinion, the law ought to give such a definition: «Defendants are persons who gave surrender, in respect of whom there are allegations of committing a crime and criminal proceedings, as well as persons, who were detained on suspicion of committing a crime, who has restraint if such persons have not been charged, and also no jurisdiction or young person in respect of which the proceedings are held to solve the issue on application of compulsory measures of educational or medical nature».

The person under investigation should be entitled to primary legal assistance from a lawyer or other legal specialist (the rules of the legal monopoly do not apply to the protection of such persons).

Consequently, it would be appropriate to introduce a new conceptual system of legal aid and protection:

1) Protection of all persons under investigation (including a suspect under modern legislation) may be provided by both lawyers and other specialists in the field of law, in respect of which there are no grounds for recusal.

2) Protection of the accused and the defendant must be done only by a lawyer, who is proposed to be called a judicial attorney and his close relatives can be as representatives of the interests of the defendant.

3) Legal assistance to victims, civil plaintiffs, civil defendants and third parties (article 63 of the Code of criminal procedure of Ukraine) 
may be provided by both lawyers and other legal experts and close relatives who may act in the procedural status of representatives of the relevant persons.

4) legal assistance to witnesses, applicants and other participants in the process may be provided by both lawyers and other specialists in the field of law, who may act in the procedural status of professional attorneys (Legal Counsel), that is, persons providing legal assistance outside the application of representation or protection.

Granting the defender the rights of the person whom he protects, the new Code of criminal procedure of Ukraine, is not coordinated with the new Law «on advocacy and advocacy», in the complicated constructions for logical understanding confused idea of parallel lawyer investigation and complicated implementation of the principle of competitiveness of the parties.

The analysis of practice shows that, firstly, the procedural rights granted to a professional defender are not enough for the realization of their tasks and socially useful professional knowledge and abilities, secondly, it is clearly not enough for adequate opposition in an adversarial trial to the prosecution, and thirdly, the rights thus granted are not clearly spelled out in the law with legal fictions and unsuccessful, vague terminology, which makes difficult to effectively use them.

In the list of the rights of the lawyer there are quite problematic definitions. For example, according to paragraph 7 of article 20 of the Law of Ukraine «on advocacy» lawyer has the right «in the manner prescribed by law to ask, receive and withdraw things, documents, copies.» Used here the concept of «withdraw», in contrast to the more correct «receive voluntarily issued» can be interpreted as their forced seizure.

But it should also be noted that the use of certain in article 20 of the Law of Ukraine «on advocacy» rights in criminal proceedings, even «defender-lawyer» is unlikely to be possible. According to part 3 of article 9 of the Code of criminal procedure of Ukraine « laws and other regulatory legal acts of Ukraine, the provisions of which relate to criminal proceedings, must comply with this Code. A law that contradicts this Code cannot be applied in criminal proceedings.» Moreover in the article 1 Code of criminal procedure 
contains the requirement - «criminal procedure in Ukraine is determined only by the criminal procedural legislation of Ukraine». In addition, according to part 1 of article 84 of the Code of criminal procedure «evidence in criminal proceedings are factual data obtained in accordance with this Code», and in accordance with part 1 of article 8 of the Code of criminal procedure « evidence is admissible if it is obtained in the manner prescribed by this Code».

Evidence in criminal proceedings may be only things, which were obtained in accordance with the procedure provided with the Code of criminal procedure. And everything else, according to the developers of the Code of criminal procedure of Ukraine - is «materials» of unknown status to science.

It should be noted that such a problem does not arise when a lawyer provides legal assistance in civil proceedings. A simpler concept is defined about admissibility of evidence - «the court does not take into account the evidence obtained in violation of the order established by law» (article 59 of the Code of civil procedure of Ukraine). And article 8 of the Code of civil procedure of Ukraine fairly defines the principle of legality more tolerant in relation to the system of law, fixing the order of this content: «the Court decides cases according to the Constitution of Ukraine, laws of Ukraine and international treaties, which were allowed by the Verkhovna Rada of Ukraine. The court shall apply other normative-legal acts adopted by the relevant body on the basis, within the powers and in the manner established by the Constitution and laws of Ukraine».

This approach is more appropriate. It is necessary to remove artificial barriers to the use in criminal proceedings of factual data obtained outside the criminal process, in the manner prescribed with other laws.

Obviously, in the current Code of criminal procedure of Ukraine artificial formalization of evidentiary law and the institution of protection was done, it contradicts the objective laws of knowledge, logic and natural law, is able to turn the trial in long process, when it will be difficult to see the concern for the fate of man. Criminal procedure legislation and the law on advocacy and legal practice need to be harmonised and substantial improvement.

It is necessary to develop and legally define in the Code of criminal procedure of Ukraine The Institute of evidentiary activity of 
the defender and legal attorney-the Institute of independent human rights investigation.

Independent human rights investigation in criminal proceedings is a separate Institute of Criminal procedural law and the activities of legal counsel and attorney based on the evidence. It consists in selfrealization in a special procedural form of the system of cognitive, practical and authoritative actions, which due to the subject and objectives of protection and legal assistance to identify sources of evidence, receipt and record the actual data, their verification and clarification belonging to the case, admissibility and reliability, enabling the use to achieve the goal of justice.

The rights of the defender about carring out evidentiary activities should be expanded and described systematically and specifically in the Code of Criminal procedure. The Institute of independent human rights investigation in criminal proceedings should include the possibility of the defender for help by the private detective in getting evidence and using the thus obtained actual data in evidence, a clear definition of the procedure for temporary access to documents, their seizure and conservation. The implementation of an independent human rights investigation in criminal proceedings should be attributed exclusively to the competence of the defender, legal counsel and the Commissioner of the Verkhovna Rada for human rights and it should not be the competence of other representatives of the defense.

The status and rights of the defender must be clearly spelled out in a separate norm in the Code of criminal procedure of Ukraine.

In particular such basic rights of the defender should be prescribed in this norm:

- to have a confidential face-to-face meeting with the detained person under investigation before his first interrogation and to provide him with the necessary legal advice, and after the first interrogation-to have a meeting with the defendant without limitation of their number and duration;

- to be present at interrogations of the client and also at implementation of other investigative actions which are carried out with his participation or at his request;

- to appeal with lawyer inquiries, including concerning receipt of copies of documents, to public authorities, local governments, their 
officials and officials, the enterprises, establishments, the organizations, public associations and also physical persons (by consent of such physical persons);

- to get acquainted with the necessary documents and materials for advocacy at enterprises, institutions and organizations, except those ones which contain information with limited access; law;

- to collect evidentiary information which is not prohibited by

- to request and receive voluntarily issued audio-video materials, electronic and other material carriers of evidentiary information, copies of documents, to make copies of documents, to interview persons with their consent;

- to use technical means, including for copying the materials of the case in which the lawyer is defender, representer or provides other types of legal assistance, to record the procedural actions in which he participates and to record the course of the court session in the manner prescribed by law;

- to contact with experts and receive written opinions of specialists, experts on issues requiring special knowledge;

- to prepare and to submit applications, complaints, petitions and other legal documents and to submit them in accordance with the procedure established by law.

Feature of activity of the defender in criminal process consists on receiving from the client the data which would not report to other person under any circumstances. The lawyer, in general, as well as the defender, in particular, is obliged to keep equally secret both the information received from the client and information about the client.

Certain guarantees of the defender should be determined in the Code of criminal procedure of Ukraine. It will be justified to note that lawyer has all guarantees, which are provided by Article 23 of the Law of Ukraine «on advocacy».

Granting a witness the right to use the help of a lawyer (article 66 of the Code of criminal procedure of Ukraine) does not solve the problem of providing him with effective legal assistance. The lawyer is the representative of the legal Institute of advocacy and he is only a potential participant in the process and may become the participant in the process only after receiving a certain procedural status, for example to protect a suspect, he receives the status of the defender, to 
provide legal support to the victim - status of the representative, and to provide legal assistance to the witness no procedural status, while remaining «just a lawyer.» There is a question- what rights will be used by him and is it admissible here to use the formula which has already been applied by the legislation «the person rendering legal aid-uses the rights of the person whom he helps». The legislator did not give an answer, leaving these questions to the conscience of law enforcement practice and legal science.

The solution of the problems we see in the need to supplement criminal procedure doctrine with the theoretical model of the Institute of legal attorney and, accordingly, to supplement the Code of criminal procedure of Ukraine with a norm «legal assistance by legal attorney».

«Legal assistance to witnesses, applicants, representatives of the legal entity in respect of which the proceedings are carried out, witnesses, pledgers, translators, experts, specialists shall be provided by legal attorneys elected by them at their discretion".

Legal attorney can act as a lawyer or his assistant and other specialist in the field of law, in respect of which there are no statutory grounds for withdrawal from participation in the case.

Legal attorney has the right to:

1) be notified about the procedural status of the person who needs a legal assistance;

2) to get acquainted with the document about the call or other documents about presence of the person in the law enforcement Agency;

3) to provide to the persons to whom the legal aid is provided, consultation on legal questions in enough volume and forms, including confidentially within time, which does not infringe the rights of other persons;

4) to apply for a change in the procedural status of a person, if it does not comply with the requirements of the law;

$5)$ to declare, in the presence of the bases provided by the law, challenge to the detective, the investigator, the prosecutor, the investigating judge, the judge;

6) to apply for the application of security measures provided for by law to the person to whom legal assistance is provided; 
7) to be present at carrying out investigative and other procedural actions which are carried out with participation of the person to whom the legal aid is rendered;

8) to explain to the person who is provided with legal assistance the right to refuse to testify and answer questions about himself, his family members and close relatives;

9) during carrying out procedural actions to put questions, to submit the remarks and objections concerning the order of carrying out actions which are brought in the Protocol;

10) get acquainted with the protocols of investigative (search) and other procedural actions performed with his participation and make written comments, clarifications and additions;

11) to apply technical means for fixing of results of procedural actions in which he is participant;

12) to submit evidence to the investigator, prosecutor, investigating judge, court;

13) to object to illegal actions of the detective, the investigator, the prosecutor, the investigating judge, the judge;

14) to provide legal assistance to a person in the preparation of written applications, complaints, petitions or claims, or with the consent of such person to make on her behalf written documents of a legal nature;

15) to file complaints against decisions, actions, inaction of the detective, the investigator, the prosecutor concerning interests of the person to whom the legal aid is rendered.

Legal attorney is obliged: to respect the rights and freedoms of human and citizen; not to impede establishment of the truth; to observe the principle of fair trial and under no circumstances to inform the court obviously incredible or unreliable information; not to disclose without the permission of the investigator, prosecutor, court, pre-trial investigation data and other information which has become known to him in connection with participation in criminal proceedings and which is the secrets protected by the law; to prevent the disclosure in any way of confidential information which has been entrusted to him or has become known in connection with the performance of his duties; to avoid committing acts which would harm the interests of the person assisted or the rights and freedoms of others»). 


\section{CONCLUSIONS}

The implementation of the constitutional foundations of legal aid and protection in criminal proceedings requires a clear definition of the procedural status of the defender, the representative of the person and the legal attorney, the development and adoption of the Institute of independent legal investigation, which should become an independent Institute of criminal procedure law.

\section{SUMMARY}

The conceptual problems of formation and development of legal aid and defense institutions in criminal proceedings are analyzed in the article, the doctrinal aspects of these institutions are revealed, the ways of improving and harmonizing legislation, eliminating legal fictions and conflicts, ensuring the effectiveness of defense and legal aid institutions are explained.

\section{REFERENCES}

1. Принципи і керівні положення Організації Об'єднаних Націй, що стосуються доступу до юридичної допомоги в системі кримінального правосуддя, Резолюція Економічного та Соціальної Ради ООН 2012/15 від 26 липня 2012 р.) URL: http://search.ligazakon.ua/1_doc2.nsf/link1/MU13168.html

2. Рішення Європейського Суду 3 прав людини від 24 листопада 2011 року «Загородній проти України», у рішенні (Заява № 27004/06) // Офіційний вісник України» від 18 травня 2012 року № 35.

3. Рішення Конституційного суду України у справі за конституційним зверненням громадянина Голованя Ігоря Володимировича щодо офіційного тлумачення положень статті 59 Конституції України (справа про правову допомогу) від 30 вересня 2009 року № 23-рп/2009. URL: http://zakon2.rada.gov.ua/laws/show/v023p710-09/conv

4. Абламський С. Є., Юхно О. О. Сучасний стан регламентації повноважень захисника за КПК України 2012 року. Часопис Національного університету «Острозька академія». Серія «Право». 2016. № 2(14). С. 1-16.

5. Адвокатура України: підручник у двох книгах / за заг. ред. д. ю. н., проф. заслуженого юриста України С. Я. Фурси та 
к. ю. н., доцента Н. М. Бакаянової. 2-ге вид. доповн. і перероб. К.: Алерта, 2016. 864 с.

6. Алейников Г. Про надання права самостійної діяльності адвоката-захисника по збиранню доказів у кримінальному проиесі. Право України. 2002. № 10. С. 100-104.

7. Балацька О. Р. Окремі проблеми забезпечення адвокатом права на захист в контексті практики Свропейського суду з прав людини. Вісник кримінального судочинства. Актуальні проблеми кримінального судочинства. 2018. № 1. С. 8-5.

8. Бірюкова А. М. Адвокатура Украӥни в умовах глобалізачї: монографія. Київ: Алерта, 2018. 424 с.

9. Біцай А. В. Участь адвоката в медіачії: монографія ; за заг. ред. д. ю.н., проф. О. Г. Яновської. К.: Алерта, 2017. 260 с.

10.Варфоломеєва Т. В. Впровадження міжнародних правил адвокатської етики в Україні. Вісник Академії адвокатури Україні. 1(14). 2009. С. 7-20.

11.Вільчик Т. Б. Конституиійне право на правову допомогу адвоката у краӥнах Європейського Союзу та в Украӥні: монографія. Харків: Право, 2015. 400 с.

12.Головань I. Правнича монополія або позбавлення конституиійного права. URL: http://blogs.pravda.com.ua

13.Гончаренко В. Г., Гончаренко С. В. Захист як соиіальна доктрина. Вісник Академії адвокатури України. 2012. Число 1 (23). С. 5-17.

14.Дроздов О., Дроздова О. Огляд справ щуодо іноземних країн, розглянутих ЄСПЛ протягом квітня травня 2016 року. Вісник НААУ. 2016. № 7-8 (25). С. 61-72.

15.Дубівка I.В. Правова регламентачія участі захисника в кримінальному прочесі за законодавством зарубіжних країн. Юридичний часопис Національної академії внутрішніх справ. 2017. № 1(13). С. 350-360.

16.Заборовський В. В. Правовий статус адвоката в умовах становлення незалежної адвокатури Украӥни: монографія. Ужгород: Видавничий дім «Гельветика», 2017. 900 с.

17.Зейкан Я. П., Сафулько С. Ф. Настільна книга адвоката у кримінальній справі (КПК 2012). Київ: Дакор, 2013. 576 с.

18.Кацавець Р. С. Судові промови державного обвинувача та адвоката-захисника у кримінальному судочинстві Украӥни: 
правові, етичні, логічні та мовні аспекти: Монографія К.: ЦУЛ. 2014. $150 \mathrm{c}$.

19.Кучинська О. П. Забезпечення права на захист та кваліфіковану правову допомогу в кримінальному провадженні. Юридична Україна. 2012. № 4. С. 65-69.

20.Маланчук П. М., Маслак О. В., Воронкова М. Ю. Актуальні проблеми участі захисника у кримінальному провадженні. Правові горизонти. 2017. № 3. С. 82-85.

21. Малахова О. В. Реалізаџія інституту сприяння захисту у кримінально-прочесуальному доказуванні. Автореферат дис. ...канд. юрид. наук. (спец. 12.00.09). Одеса, 2015. 20 с.

22. Маляренко В. Т. Про сумні тенденції в розвитку інститут захисту в Украӥні. Адвокат. 2001. № 1-2. С. 42-75.

23.Маслюк О. В. Адвокатське розслідування у кримінальному судочинстві: міжнародний досвід та світові стандарти. Право і суспільство. 2017. № 3. С. 97-101.

24.Михайлова Н. В. Інститут захисту прав потерпілого за новим КПК Украӥни. Право і суспільство. 2013. № 2. С. 211-216.

25.Моторигіна М. Г. Сторона захисту в судовому провадженні у першій інстаниії. Монографія. Харків. 2018.

26.Несінов О. Н. Складові успіху у кримінальному прочесі. Книга друга. Харків: “Видавництво “Права людини”, 2019. 624 с.

27.Нестор Н. В. Запровадження медіації в кримінальному прочесі Украӥни: проблеми теорії та практики: монографія. К.: Алерта, 2018. $182 \mathrm{c.}$

28.Никоненко М. Деякі питання презумпиії невинуватості $i$ права особи на захист в кримінальному процесі. Право України. 1999. № 4. С. 39-40.

29.Нор В., Войнарович А. Адвокат як єдиний суб'єкт надання правничої допомоги у судовому провадженні: міжнародний досвід та вітчизняні законодавчі новели. Law of Ukraine. 2016, Issue 12, p. 9-18. 10 p.

30.Оверчук С. В. Обмеження права вибору захисника у світлі європейських стандартів. Часопис Національного університету «Острозька академія». Серія «Право». 2016. № 2(14). . URL:http://lj.oa.edu.ua/articles/2016/n2/16osvsys.pdf. 
31.Одинцова I. М. Інститут самостійного адвокатського розслідування у кримінальному прочесі. Правова позиція. 2016. № 2(17). C. 170-175.

32.Острогляд О. В. Діяльність захисника в апеляиійному провадженні. Навчальний посібник. Івано-Франківськ: Прикарпатський національний університет імені Василя Стефаника, 2010. 162 с.

33.Письменний Д. П. Функції обвинувачення та захисту за новим КПК Украӥни. Право і суспільство. 2013. № 2. С. 353-358.

34.Пономаренко Д. В. Тактичні питання захисту в кримінальному провадженні. Книга перша: практ. посіб. Одеса: Видавничий дім «Гельветика», 2018. 112 с.

35.Попелюшко В. О. Функиія захисту в кримінальному прочесі на сучасному етапі. Адвокат. 2008. № 8. С. 7-12.

36.Рибалка О. В. Захисник як суб'єкт доказування в кримінальній справі. Адвокат. 2011. № 7(130). С. 35-40.

37.Русанова О. Г. Прочесуальне представництво адвоката у кримінальному прочесі як гарантія захисту конституційних прав потерпілого. Адвокат. 2012. № 2. С. 42-45.

38.Сачко О. В. Проблеми дієвості інституту захисту в кримінальному прочесі. Актуальні проблеми вітчизняної юриспруденції. 2017. № 2. С. 142-145.

39.Сачко О. В. Проблеми реалізаџіï верховенства права при застосуванні особливих форм та режимів кримінального провадження. Монографія. Дніпропетровськ: Дніпровський національний університет ім. Олеся Гончара; Ліра ЛТД, 2018. $404 \mathrm{c}$.

40.Скрябін О. М. Участь захисника в окремих кримінальних провадженнях: монографія. Запоріжжя: Просвіта, 2017. 380 с.

41.Смирнов С. В. Статус захисника як суб 'єкта доказування y кримінальному судочинстві. Підприємство, господарство і право. 2014. № 12 (228). С. 82-85.

42.Сопілко I. М. Місие та роль сучасної адвокатури України в правозахисному механізмі. Юридичний вісник. 2012. № 1 (22). C. 82-86.

43.Татаров О. Ю., Чернявський С. С. Участь захисника у кримінальному провадженні: проблеми законодавчого 
врегулювання Вісник кримінального судочинства. 2015. № 2. C. $77-83$.

44. Тертишник В. М. Кримінальний прочес України: підручник. 7-ме вид., доповн. і перероб. К.: Алерта, 2017. 840 с.

45.Тертишник В. М., Одинцова I. М. Правнича допомога ma захист в кримінальному процесі: концепти та колізї правових реформ. Наше право. 2017. № 4. С. 164-171.

46.Тертишник В. М. Правнича допомога та захист $y$ кримінальному проиесі: Підручник / За заг. ред. д.ю.н., академіка НАН України Ю. С. Шемшученко. Київ: Алерта, 2018. 480 с.

47.Фіолевський Д. П. Закон України «Про адвокатуру та адвокатську діяльність». Коментар. К.: Алерта, 2013. 368 с.

48.Хмелевська Н. В. Стратегія забезпечення правової допомоги адвокатом в кримінальному провадженні. Вісник Академії адвокатури України. Том 12. Число 2(33) 2015. C. 193-201.

49.Цимбал-Семенчук I. Ю. Правовий статус захисника у кримінальному судовому провадженні: національно-правове регулювання. Науковий вісник Херсонського державного університету. Серія: Юридичні науки. 2013. Вип. 6. Том 2. С. $146-149$.

50.Яновська О. Г. Процесуальні форми протестної діяльності адвоката в кримінальному провадженні. Право України. 2013. № 11. С. 165-172.

\section{Information about the author:} Tertyshnik V. M., Doctor of Law, Professor, Academician of the Academy of Political Sciences of Ukraine, Professor of the University of Customs and Finance 2/4, Volodymyra Vernadskoho Str., Dnipro, Ukraine 